\title{
Congenital Musculoskeletal Defect
}

National Cancer Institute

\section{Source}

National Cancer Institute. Congenital Musculoskeletal Defect. NCI Thesaurus. Code C89337.

An abnormality of the musculoskeletal system that is present at birth or detected in the neonatal period. 